KAROLINA CZERWIEC

KATARZYNA POTYRAŁA

Forum Pedagogiczne

2016/2 cz. 2

BEATA JANCARZ-ŁANCZKOWSKA

Wpłynęło: 12.05.2016

Uniwersytet Pedagogiczny im. Komisji Edukacji Narodowej

Kraków

\title{
ZACHOWANIA PROZDROWOTNE MLODZIEŻY. RAPORT Z BADAŃ WSTĘPNYCH PROWADZONYCH PRZEZ STUDENTÓW - PRZYSZŁYCH NAUCZYCIELI
}

\begin{abstract}
Streszczenie: Zrównoważony rozwój społeczeństw w dużej mierze zależy od realizacji koncepcji kształcenia w obszarze poszanowania i ochrony zdrowia człowieka. Współczesna edukacja powiązana jest ze zmianami w podejściu do wiedzy szkolnej i społecznej. Jednym z elementów tej wiedzy jest kształtowanie odpowiedzialności za zdrowie swoje i innych (Potyrała 2011). Dlatego przy pomocy arkuszy obserwacji wypełnianych przez studentów biologii - przyszłych nauczycieli - przeprowadzono badania na terenie kilkudziesięciu szkół gimnazjalnych i ponadgimnazjalnych. Ich celem była analiza zachowań prozdrowotnych uczniów oraz realizacji zasad edukacji zdrowotnej przez szkoły. Włączenie do przebiegu praktyki pedagogicznej prowadzenia badań miało na celu rozwijanie u studentów kompetencji w zakresie obserwacji wybranych obszarów działalności szkoły. Analiza danych dotyczących realizacji idei zrównoważonego rozwoju w obszarze ochrony zdrowia uczniów w gimnazjach i liceach ogólnokształcących dostarczyła informacji, że świadomość prozdrowotna w polskich szkołach wzrasta, a zaangażowanie nauczycieli i uczniów w działania na rzecz zdrowia (higieny, odpowiedniego żywienia, aktywności fizycznej) jest coraz większe i bardziej wielostronne.
\end{abstract}

Słowa kluczowe: rozwój zawodowy, zrównoważony rozwój, edukacja dla zrównoważonego rozwoju, edukacja zdrowotna, zdrowie człowieka, gimnazjum, liceum, student, nauczyciel

\section{Wstęp}

Zdrowie jest uznawane za podstawowe pojęcie w edukacji, a 65\% dorosłych Polaków wymienia je jako warunek szczęśliwego życia (Woynarowska 2007). Konwencja o prawach dziecka przyjęta przez ONZ w 1989 roku ustanowiła edukację zdrowotną podstawowym prawem wszystkich dzieci. Promowanie właściwych postaw zdrowotnych jest ideą globalną. Na całym świecie podejmowane są działania, których celem jest ochrona i umacnianie zdrowia (Callcott i in. 2012; Davis, Cooke 2007; 
Glanz i in. 2015; Orme, Dooris 2010; Rezolucja Rady Unii Europejskiej 2009). Jednym z kluczowych komponentów szkolnych programów nauczania jest edukacja zdrowotna, której celem jest promowanie indywidualnych i społecznych aspektów dbałości o zdrowie oraz rozwój umiejętności potrzebnych do stworzenia warunków sprzyjających zdrowiu. Odpowiedzialne za ten proces są rodzina, system edukacji i społeczeństwo (Podstawa programowa kształcenia ogólnego z komentarzami 2009). Nowoczesna edukacja zdrowotna powinna opierać się na nabywaniu wiedzy i umiejętności na temat: chorób i funkcjonowania organizmu, opieki zdrowotnej oraz korzystania z niej, oddziaływania czynników społecznych, politycznych i środowiskowych na zdrowie człowieka. Głównym celem działań szkoły jest organizowanie środowiska sprzyjającego utrzymaniu zdrowia oraz promowanie zachowań i kompetencji prozdrowotnych wśród dzieci, młodzieży i lokalnej społeczności.

\section{Zakres merytoryczny i metodyczny realizacji idei zrównoważonego rozwoju w obszarze ochrony zdrowia, wynikający $\mathrm{z}$ wymagań podstawy programowej kształcenia ogólnego}

Strategia edukacji dla zrównoważonego rozwoju (EZR) znalazła swoje odzwierciedlenie w zapisach podstawy programowej kształcenia ogólnego z 23 grudnia 2008 roku (z późniejszymi zmianami) w postaci spisu koniecznych do omówienia zagadnień oraz kształtowanych na danym etapie edukacyjnym kompetencji uczniów. Jednocześnie sposób sformułowania w podstawie programowej wymagań ogólnych i szczegółowych rzutuje na dobór przez nauczyciela metod i technik nauczania.

Nowe cele edukacji zdrowotnej zostały przedstawione w komentarzu do podstawy programowej z 2008 roku, jest tam mowa o: poznaniu przebiegu swojego rozwoju; zrozumieniu, czym jest zdrowie, od czego zależy, dlaczego i jak należy o nie dbać; rozwijaniu poczucia odpowiedzialności za zdrowie własne i innych; wzmacnianiu wiary w swoje możliwości; rozwijaniu umiejętności osobistych i społecznych sprzyjających dobremu samopoczuciu i adaptacji do codziennego życia; przygotowaniu się do uczestnictwa $\mathrm{w}$ działaniach na rzecz zdrowia oraz tworzenia zdrowego środowiska $\mathrm{w}$ domu, szkole, miejscu pracy i lokalnej społeczności (Podstawa programowa kształcenia ogólnego $z$ komentarzami 2009). Osiągnięcie tych celów wiąże się jednak z podjęciem różnorodnych działań w ramach programu dydaktycznego, wychowawczego oraz szkolnego programu profilaktyki. Proces ten jest długotrwały i wymaga zaangażowania uczniów oraz ich rodziców, gdyż skuteczność edukacji zdrowotnej zależy od tego, czy dzieci przeniosą do swojego codziennego życia to, czego nauczyły się w szkole (Callcott i in. 2012; Glanz i in. 2015; Purchałka, Czerwiec 2013).

Podczas realizacji zagadnień dotyczących zdrowia na lekcjach biologii w gimnazjum i liceum uczeń powinien: analizować uwarunkowania zdrowia człowieka (takie jak prawidłowa dieta, aktywność ruchowa, badania profilaktyczne) i związek 
pomiędzy własnym postępowaniem a zachowaniem zdrowia, rozpoznawać sytuacje wymagające konsultacji lekarskiej, przedstawiać znaczenie zdrowia fizycznego, psychicznego i społecznego oraz choroby jako zaburzenia stanu równowagi, przedstawiać negatywny wpływ na zdrowie człowieka substancji psychoaktywnych, narkotyków i środków dopingujących oraz nadużywania kofeiny i niektórych leków, wymieniać najważniejsze choroby człowieka wywoływane przez wirusy, bakterie, protisty i pasożyty zwierzęce oraz przedstawiać zasady profilaktyki tych chorób, w szczególności zakażenia HIV, HBV i HCV oraz HPV, przedstawiać czynniki sprzyjające rozwojowi choroby nowotworowej, uzasadniać konieczność okresowego wykonywania podstawowych badań kontrolnych (Podstawa programowa kształcenia ogólnego 2012).

Edukacja dla zrównoważonego rozwoju odbywa się nie tylko w czasie lekcji biologii, ale także podczas codziennego funkcjonowania uczniów w środowisku szkolnym poprzez reprezentowanie odpowiednich zachowań i udział w działaniach szkoły promujących tę ideę.

\section{Metodologia i organizacja badań}

Cele badań:

- rozwijanie kompetencji zawodowych studentów - przyszłych nauczycieli w zakresie prowadzenia obserwacji środowiska szkolnego,

- diagnoza stopnia realizacji idei zrównoważonego rozwoju w gimnazjach i liceach ogólnokształcących.

Metody badawcze:

- analiza dokumentów: programu studiów na kierunku biologia oraz specjalności biologia z chemią, Rozporządzenia Ministra Nauki i Szkolnictwa Wyższego $z$ dnia 17 stycznia $2012 r$. w sprawie standardów ksztatcenia przygotowujacego do wykonywania zawodu nauczyciela, programów nauczania biologii dla III i IV etapu edukacyjnego,

- obserwacja.

Narzędzia badawcze:

- przewodnik do analizy podstawy programowej kształcenia ogólnego oraz programów nauczania biologii,

- arkusze obserwacji.

Organizacja badań:

Przeprowadzono je w latach 2014-2016. Przed rozpoczęciem badań przez studentów autorzy niniejszego opracowania dokonali analizy programów studiów na kierunku biologia oraz programu specjalności nauczycielskiej biologia $\mathrm{z}$ chemią Uniwersytetu Pedagogicznego w Krakowie pod kątem wiedzy, umiejętności i kompetencji społecznych studentów, przyszłych nauczycieli biologii, w zakresie prowadzenia samodzielnej diagnozy pedagogicznej. Zapisy programów studiów skonfrontowano ze standardami kształcenia przygotowującego do wykonywania zawodu nauczyciela. 
Analizę programów nauczania biologii oraz obserwacje pedagogiczne prowadzili studenci biologii Uniwersytetu Pedagogicznego w Krakowie, odbywający praktyki pedagogiczne w gimnazjach i liceach ogólnokształcących. Po rozpoczęciu praktyk pedagogicznych mieli dokonać analizy programów nauczania biologii obowiązujących w szkole, w której odbywali praktykę, pod kątem treści dotyczących zdrowia. $\mathrm{W}$ sumie przeanalizowano 10 programów nauczania biologii (6 do gimnazjum oraz 4 do liceum ogólnokształcącego). Badanie zostało wykonane zgodnie z jednolitym przewodnikiem analizy programu. Wyszukiwano w programach hasła programowe dotyczące tematyki prozdrowotnej. Na podstawie uzupełnionych dla każdej szkoły przewodników analizy programów określono częstość pojawiania się haseł ogólnych i szczegółowych.

Następnie studenci przystąpili do obserwacji zgodnie z ustalonymi zasadami. Przeprowadzili je w 105 szkołach Krakowa oraz mniejszych miejscowości województwa małopolskiego i podkarpackiego, w tym 75 gimnazjach i 30 liceach ogólnokształcących. Przed rozpoczęciem badań obserwatorzy zostali odpowiednio przygotowani i zaopatrzeni $w$ instrukcję oraz arkusze obserwacji opracowane na podstawie literatury (Angrosino 2010). Arkusz został podzielony na obszary: higiena i zdrowie fizyczne, żywienie, zdrowie psychiczne, aktywność fizyczna. Ustalono, że przeprowadzający badanie w każdej szkole dokonywali zwartego, niewartościującego zapisu zdarzeń zaobserwowanych w poszczególnych obszarach przez 5 dni podczas tzw. długiej przerwy oraz przez 20 minut po lekcjach zakończonych w danym dniu. Część informacji niezbędnych do uzupełnienia arkusza pozyskiwali podczas rozmów z członkami społeczności szkolnej, a także analizując dostępną praktykantom dokumentację pracy szkoły taką jak: zapisy tematów lekcji w dziennikach lekcyjnych, podział godzin, harmonogram zajęć pozalekcyjnych. Arkusze obserwacji opatrzone nazwiskiem i imieniem obserwatora zostały następnie poddane analizie porównawczej w obrębie obszarów obserwacji osobno dla poszczególnych typów szkół: gimnazjów i liceów ogólnokształcących. Następnie skategoryzowano obserwowane zjawiska związane ze zdrowiem i promowaniem zachowań prozdrowotnych oraz określono procentowo częstość ich występowania w badanych szkołach.

\section{Wyniki}

Wiedza, umiejętności i kompetencje społeczne wynikające z analizy programu studiów na kierunku biologia oraz programu specjalności nauczycielskiej biologia $\mathrm{z}$ chemią

Z kierunkowych efektów kształcenia w obszarze wiedzy, umiejętności i kompetencji społecznych wybrano te zapisy, które bezpośrednio i pośrednio dotyczyły zagadnień związanych ze zdrowiem człowieka oraz z wybraną specjalnością, czyli przygotowaniem do wykonywania zawodu nauczyciela biologii w gimnazjum i szkole ponadgimnazjalnej (tabela 1.; w nawiasach podano liczbę efektów związanych 
z tematem badań w stosunku do wszystkich zaplanowanych efektów dla kierunku i specjalności).

Tabela 1. Kierunkowe efekty kształcenia w obszarach wiedzy, umiejętności i kompetencji społecznych w programach studiów na kierunku biologia

\begin{tabular}{ll}
\hline Obszary & Kierunkowe efekty kształcenia \\
\hline Wiedza & Student: \\
& - dokonuje wieloaspektowej analizy porównawczej mechanizmów \\
& molekularnych, komórkowych i fizjologicznych funkcjonowania \\
& organizmów; \\
& - dostrzega dynamiczny rozwój nauk biologicznych oraz powstawanie \\
& nowych kierunków i dyscyplin badawczych; \\
& - wskazuje najistotniejsze trendy rozwoju nauk biologicznych w zakre- \\
& sie studiowanej przez siebie specjalności; \\
& - określa podstawowe zasady bezpieczeństwa i higieny pracy oraz \\
& ergonomii. \\
\hline Umiejętności & Student: \\
& - wykazuje umiejętność krytycznej analizy i selekcji informacji biolo- \\
& gicznych, zwłaszcza ze źródeł elektronicznych; \\
& - planuje i wykonuje zadania badawcze lub ekspertyzy z zakresu stu- \\
& diowanej specjalności biologicznej pod kierunkiem opiekuna; \\
& - wykorzystuje zdobytą wiedzę specjalistyczną do interpretacji zebra- \\
& nych danych empirycznych oraz wnioskowania; \\
& - konfrontuje krytycznie informacje biologiczne pochodzące z róż- \\
& nych źródeł i na tej podstawie wyciąga uzasadnione wnioski; \\
& - samodzielnie planuje własną karierę zawodową/naukową w kie- \\
& runku wykorzystującym uzyskane kwalifikacje biologiczne. \\
\hline Kompetencje & Student: \\
& - ma świadomość odpowiedzialności za wspólnie realizowane \\
& zadania; \\
& - systematycznie aktualizuje wiedzę biologiczną i informacje o jej \\
& praktycznych zastosowaniach; \\
& - wdraża i rozwija zasady etyki zawodowej; \\
& - wykazuje inicjatywę i samodzielność w działaniach; \\
& - w ocenie pracy współpracowników dąży do zachowania postawy \\
& obiektywnej. \\
\hline & \\
& \\
& \\
&
\end{tabular}

Źródło: opracowanie własne na postawie planów i programów studiów na kierunku biologia Uniwersytetu Pedagogicznego w Krakowie

Studenci kierunku biologia z rocznika, który prowadził badania podczas praktyk pedagogicznych, mieli możliwość wyboru specjalności biologia z chemią, gdzie 
przygotowuje się do nauczania biologii i chemii w gimnazjach i szkołach ponadgimnazjalnych oraz przyrody w liceach ogólnokształcących (tabela 2.).

Tabela 2. Efekty kształcenia w obszarze wiedzy, umiejętności i kompetencji społecznych w programach specjalności nauczycielskiej biologia z chemią

\begin{tabular}{ll}
\hline Obszary & Efekty kształcenia \\
\hline Wiedza & Student: \\
( z z 6) & - posiada wiedzę psychologiczną i pedagogiczną pozwalającą na \\
& rozumienie procesów rozwoju, socjalizacji, wychowania i nauczania - \\
& uczenia się; \\
& - zna terminologię używaną w dydaktyce przedmiotów przyrod- \\
& niczych do opisywania procesu dydaktyczno-wychowawczego oraz \\
& kształcenia przyrodniczego w szkole; \\
& - posiada wiedzę na temat organizacji procesu kształcenia biologicz- \\
& nego i przyrodniczego: celów i treści kształcenia, środków dydaktycz- \\
& nych i metod kształcenia.
\end{tabular}

Umiejętności Student:

(4 $\mathrm{z} 7)$ - posiada umiejętności i kompetencje niezbędne do kompleksowej realizacji dydaktycznych, wychowawczych i opiekuńczych zadań szkoły, w tym samodzielnego przygotowania i dostosowania programu nauczania do potrzeb i możliwości uczniów;

- wykazuje umiejętność uczenia się i doskonalenia własnego warsztatu pedagogicznego z wykorzystaniem nowoczesnych środków i metod pozyskiwania, organizowania i przetwarzania informacji i materiałów; - komunikuje się umiejętnie przy użyciu różnych technik zarówno z osobami będącymi podmiotami działalności pedagogicznej, jak i współdziałającymi w procesie dydaktyczno-wychowawczym oraz specjalistami wspierającymi ten proces;

- wykorzystuje znajomość poznanych teorii nauczania do organizowania i planowania lekcji biologii i rozwijania zainteresowań przyrodniczych uczniów.

Kompetencje Student:

społeczne - charakteryzuje się wrażliwością etyczną, empatią, otwartoś-

(2 z 2) cią, refleksyjnością oraz postawami prospołecznymi i poczuciem odpowiedzialności;

- jest praktycznie przygotowany do realizowania zadań zawodowych (dydaktycznych, wychowawczych i opiekuńczych) wynikających z roli nauczyciela.

Źródło: opracowanie własne na postawie planów i programów studiów na kierunku biologia Uniwersytetu Pedagogicznego w Krakowie.

Wśród oczekiwanych efektów kształcenia kierunkowego i specjalnościowego prawie w każdej kategorii co najmniej połowa odnosi się do obszarów dotyczących 
niniejszego opracowania. Absolwent kierunku biologia, kończący jednocześnie specjalność nauczycielską, wyposażony w nowoczesną, specjalistyczną wiedzę biologiczną, umiejętności interpretacji informacji pochodzących z różnych źródeł, a także kompetencje społeczne odpowiednie do zarządzania procesami grupowymi, jest jak najbardziej predysponowany do pełnienia roli lidera działań prozdrowotnych w społeczności szkolnej. Nabycie podczas praktyki pedagogicznej umiejętności wnikliwej obserwacji środowiska szkolnego przygotowuje natomiast do poprawnego ewaluowania i sprawnego planowania kolejnych, adekwatnych do potrzeb danego środowiska, działań w zakresie promocji zdrowia.

Wyniki analizy programów nauczania biologii obowiązujących w szkołach objętych badaniem

We wszystkich poddanych analizie programach nauczania biologii w liceum najczęściej pojawiającymi się hasłami dotyczącymi zdrowia są:

1. profilaktyka chorób, promowanie zdrowego stylu życia, racjonalne odżywianie i higiena,

2. aktywność na lekcjach wychowania fizycznego,

3. choroby genetyczne człowieka,

4. różnorodność wirusów, bakterii, protistów i grzybów, ich wpływ na zdrowie i życie,

5. budowa i funkcje układów narządów, zaburzenia ich funkcjonowania.

Hasła z zakresu zdrowia, które wystąpiły we wszystkich analizowanych programach nauczania biologii w gimnazjum, to:

1. znaczenie aktywności fizycznej i ćwiczeń rekreacyjnych,

2. budowa i funkcje układów narządów, profilaktyka chorób,

3. zbilansowana dieta, wartość energetyczna składników odżywczych, model zdrowego odżywiania,

4. choroby cywilizacyjne, zdrowie psychiczne i fizyczne, emocje i odporność na stres.

Tematyka programów nauczania biologii realizowana w gimnazjum i liceum w dużej mierze się ze sobą pokrywa. W liceum w mniejszym stopniu niż w gimnazjum porusza się zagadnienia dotyczące żywienia i zróżnicowanej diety. Z kolei aktywność fizyczna, zarówno w gimnazjum, jak i liceum, jest obecna wyłącznie na poziomie podstawowym. 
Wyniki obserwacji - edukacja dla zrównoważonego rozwoju w zakresie zachowań zdrowotnych członków społeczności szkolnej gimnazjów i liceów

Częstotliwość obserwowanych zjawisk związanych ze zdrowiem i promowaniem zachowań prozdrowotnych w badanych gimnazjach i liceach zawarto w tabeli 3 .

Tabela 3. Częstotliwość obserwowanych zjawisk związanych ze zdrowiem i promowaniem zachowań prozdrowotnych $w$ badanych gimnazjach i liceach (zachowano sformułowania zaproponowane przez studentów)

\begin{tabular}{|c|c|c|c|}
\hline \multirow{2}{*}{\multicolumn{2}{|c|}{ Zaobserwowane zjawiska }} & \multicolumn{2}{|c|}{ \% szkół/uczniów } \\
\hline & & gimnazjum & liceum \\
\hline \multirow{12}{*}{ 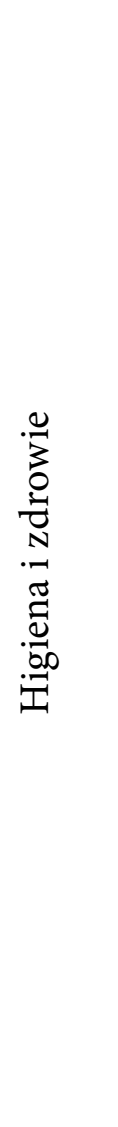 } & $\begin{array}{l}\text { Czas trwania przerw zależnie od pory dnia od } 5 \text { do } 20 \\
\text { minut }\end{array}$ & 100 & 100 \\
\hline & Korytarze monitorowane podczas dyżurów nauczycieli & 100 & 95 \\
\hline & $\begin{array}{l}\text { Pokoje nauczycielskie duże, dobrze wyposażone } \\
\text { w aneksy kuchenne, szafki, odpowiednią liczbę krzeseł }\end{array}$ & 70 & 80 \\
\hline & $\begin{array}{l}\text { Niewłaściwe siedzenie uczniów w ławkach (kołysanie } \\
\text { się na krzesłach) }\end{array}$ & 80 & 80 \\
\hline & Noszenie plecaków na jednym ramieniu & 70 & 85 \\
\hline & Otyłość uczniów & 10 & 10 \\
\hline & Problem palenia papierosów & 30 & 30 \\
\hline & $\begin{array}{l}\text { Podejmowanie działań eliminujących palenie papiero- } \\
\text { sów przez uczniów }\end{array}$ & - & 20 \\
\hline & $\begin{array}{l}\text { Dobrze wyposażone toalety ( } \mathrm{z} \text { dostępem do mydła } \\
\text { i ręczników) }\end{array}$ & 95 & 85 \\
\hline & Dobre oświetlenie szkoły & 100 & 100 \\
\hline & $\begin{array}{l}\text { Edukacja w zakresie profilaktyki antynikotynowej } \\
\text { i antyalkoholowej (gazetki i plakaty na korytarzach } \\
\text { szkolnych) }\end{array}$ & 100 & 60 \\
\hline & Tematy lekcji związane z profilaktyką prozdrowotną & - & 30 \\
\hline \multirow{3}{*}{ 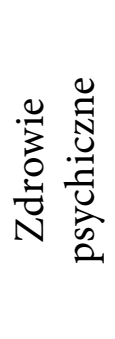 } & $\begin{array}{l}\text { Dobre relacje między nauczycielami a uczniami (uwagi } \\
\text { nauczycieli adekwatne do zachowań uczniów) }\end{array}$ & 100 & \multirow{3}{*}{$\begin{array}{c}\text { brak } \\
\text { danych }\end{array}$} \\
\hline & $\begin{array}{l}\text { Kulturalne zachowanie uczniów wobec nauczycieli } \\
\text { (sporadycznie zdarzające się wulgaryzmy, wypowia- } \\
\text { dane przypadkiem podczas przerw) }\end{array}$ & 100 & \\
\hline & Dostęp uczniów do pedagoga szkolnego & 100 & \\
\hline
\end{tabular}




\begin{tabular}{|c|c|c|c|}
\hline \multirow{2}{*}{\multicolumn{2}{|c|}{ Zaobserwowane zjawiska }} & \multicolumn{2}{|c|}{ \% szkół/uczniów } \\
\hline & & gimnazjum & liceum \\
\hline \multirow{11}{*}{ 离 } & Przerwa obiadowa po godzinie 12 & 100 & 100 \\
\hline & Śniadanie w postaci kanapek spożywane na korytarzu & 90 & 40 \\
\hline & Darmowe posiłki dla uprawnionych uczniów & 80 & - \\
\hline & Stołówka szkolna & 80 & 70 \\
\hline & $\begin{array}{l}\text { Sklepik szkolny: chipsy, batony, słodkie gazowane } \\
\text { napoje }^{*}\end{array}$ & 95 & 80 \\
\hline & Długie kolejki do sklepików szkolnych podczas przerw & 80 & 70 \\
\hline & Wychodzenie do sklepów poza terenem szkoły & - & 20 \\
\hline & $\begin{array}{l}\text { Automaty z tzw. niezdrową żywnością (batonami, } \\
\text { gazowanymi słodkimi napojami)* }\end{array}$ & - & 60 \\
\hline & Automaty z wodą na korytarzach & 30 & - \\
\hline & $\begin{array}{l}\text { Promowanie zdrowego odżywiania poprzez gazetki } \\
\text { ścienne i plakaty na korytarzach }\end{array}$ & 100 & 30 \\
\hline & $\begin{array}{l}\text { Lekcje na temat zdrowego żywienia, spotkania z diete- } \\
\text { tykiem i lekarzem }\end{array}$ & 10 & 20 \\
\hline \multirow{15}{*}{ 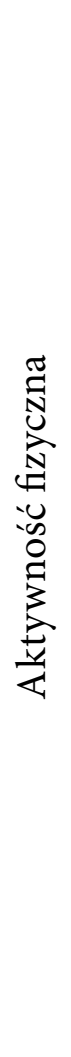 } & Duże, dobrze wyposażone sale gimnastyczne & 90 & 95 \\
\hline & Boiska szkolne dostępne dla uczniów w okresie letnim & 100 & 100 \\
\hline & Sale gimnastyczne dostępne tylko podczas lekcji wf. & 80 & 70 \\
\hline & Urozmaicone ćwiczenia na lekcjach wf. & 20 & 20 \\
\hline & Nauka pływania na basenie & 40 & 80 \\
\hline & Zawody sportowe organizowane przez szkołę & 100 & 100 \\
\hline & Koła sportowe & 100 & 100 \\
\hline & Fitness, zumba, aerobik w formie zajęć pozalekcyjnych & 40 & 10 \\
\hline & Nauka sztuk walki jako zajęcia pozalekcyjne & 20 & - \\
\hline & Częste zwolnienia z wf. & 40 & 40 \\
\hline & $\begin{array}{l}\text { Podczas przerw uczniowie siedzą pod salami } \\
\text { lekcyjnymi }\end{array}$ & 70 & 80 \\
\hline & $\begin{array}{l}\text { Brak pryszniców lub możliwości korzystania z nich po } \\
\text { wf. }\end{array}$ & - & 60 \\
\hline & Uczniowie dojeżdżają do szkoły komunikacją miejską & \multirow{3}{*}{$\begin{array}{l}\text { brak } \\
\text { danych }\end{array}$} & 60 \\
\hline & Uczniowie dojeżdżają do szkoły rowerami & & 10 \\
\hline & Uczniowie dojeżdżają do szkoły samochodami & & 30 \\
\hline
\end{tabular}

* Obserwacje prowadzono przed wejściem w życie Rozporządzenia Ministra Zdrowia z dnia 26 sierpnia 2015 r. w sprawie grup środków spożywczych przeznaczonych do sprzedaży dzieciom i młodzieży $w$ jednostkach systemu oświaty oraz wymagań, jakie musza spetniać środki spożywcze stosowane w ramach żywienia zbiorowego dzieci i młodzieży w tych jednostkach (Dz.U. 2015, poz. 1256) 
Nad bezpieczeństwem i relacjami gimnazjalistów czuwają nauczyciele dyżurujący na korytarzach szkolnych. Niestety, zauważono problem palenia papierosów przez uczniów - we wszystkich obserwowanych szkołach znajdują się plakaty i ulotki na temat szkodliwości nałogów, jednak część z nich nosi znamiona starości (są zakurzone, wyblakłe lub pożółkłe).

Warunki w pokojach nauczycielskich są różne. W niektórych szkołach pomieszczenia są małe i ciemne, nie ma w nich wystarczającej liczby miejsc siedzących, $\mathrm{w}$ innych $\mathrm{z}$ kolei są bardzo dobrze wyposażone $\mathrm{w}$ aneksy kuchenne, stanowiska komputerowe i indywidualne szafki zamykane na kod/klucz.

Uczniowie w przeważającej większości używają plecaków noszonych na jednym ramieniu (chłopcy) lub torebek (dziewczęta). We wszystkich szkołach nauczyciele twierdzą, że zwracają uwagę na niewłaściwy sposób noszenia plecaków oraz pozycje, w jakich uczniowie siedzą na krzesłach.

Niemal we wszystkich szkołach są czyste toalety, a w nich środki higieniczne. Tylko w dwóch brakuje podstawowych środków, takich jak mydło, ręczniki i papier toaletowy, co utrudnia zachowanie podstawowych zasad higieny.

W szkołach znajdują się sklepiki szkolne, w których uczniowie mają możliwość zakupienia zdrowej żywności (jabłek, bananów, wody), a także niezdrowej (chipsów, batonów, kolorowych napojów). Niektóre szkoły posiadają automaty z żywnością i napojami oraz bardzo dobrze prosperujące stołówki, serwujące domowe, zróżnicowane, tanie obiady (80\% szkół). Zdarzają się też przypadki cateringu (3 szkoły), gdzie ceny obiadów są dość wysokie, co skutkuje małą liczbą korzystających z nich uczniów. Uczniowie przynoszą drugie śniadania z domu, głównie w postaci kanapek, drożdżówek, zimnych napojów i słodyczy, które spożywają w salach lekcyjnych, na korytarzach i w stołówkach. W każdej szkole zaobserwowano przypadki nadwagi i otyłości uczniów.

Aktywność fizyczna w szkołach jest na różnym poziomie. W przypadku jednej szkoły nauczyciele wf. przez cały czas trwania praktyki byli na zwolnieniu lekarskim, co utrudniało regularne realizowanie zajęć. Jednakże zdecydowana większość szkół jest dobrze wyposażona w sale gimnastyczne, siłownie, boiska szkolne, salki do fitnessu, a nawet ścianki wspinaczkowe i sale do nauki sztuk walki.

Pokoje nauczycielskie w liceach ogólnokształcących z reguły są przestronne i dobrze wyposażone, choć zdarzają się też ciasne, małe i nieprzystosowane do potrzeb pedagogów. Nauczyciele do szkół dojeżdżają głównie samochodami, a uczniowie komunikacją miejską, rzadziej rowerami, nieliczni samochodami.

Zaobserwowano stosunkowo dobre wyposażenie toalet w szkołach. W zdecydowanej większości z nich znajdują się: papier toaletowy, mydło i suszarki do rąk, rzadziej ręczniki jednorazowe.

W toaletach zaobserwowano oznaki palenia papierosów, jednak nie wydaje się, by było to zjawisko powszechne (uczniowie raczej opuszczają szkołę w celu palenia). Jednocześnie część szkół prowadzi działania profilaktyczne w tym zakresie - w toaletach wiszą znaczki „zakaz palenia” i plakaty ostrzegające o szkodliwości nałogu. 
Treści prozdrowotne pojawiły się w jednej trzeciej badanych szkół, ale były związane z realizacją tematów na lekcjach biologii. Nie odnotowano, aby zagadnienia prozdrowotne były poruszane na godzinach wychowawczych. Natomiast w kilku szkołach nauczyciele deklarowali, że organizują spotkania z lekarzami lub dietetykami na temat zdrowego odżywiania.

Na korytarzach szkolnych w zdecydowanej większości szkół brak jest ławek lub stolików, przy których w czasie przerw uczniowie mogliby usiąść i spożyć śniadanie. Często więc pozostają podczas przerw w salach lub jedzą śniadanie, stojąc na korytarzach. Stosunkowo rzadko przynoszą jedzenie z domu, natomiast często wychodzą do sklepów w okolicy szkoły. W każdej szkole dostępna jest tzw. niezdrowa żywność, można ją kupić w sklepiku lub w automacie. W części z nich znajdują się bufety lub stołówki, w których można kupić ciepły posiłek. W każdej szkole zauważono przypadki nadwagi i otyłości.

Uczniowie noszą książki w plecakach lub torbach, najczęściej zawieszonych na jednym ramieniu. Częste są również zwolnienia z zajęć wf. (głównie dziewcząt). Większość szkół jest dobrze wyposażona w sale gimnastyczne, siłownie, boiska szkolne, jednak nie są one zwykle dostępne dla uczniów po lekcjach. W większości badanych szkół uczniowie nie korzystają z pryszniców. Są one niedostępne lub szkoły w ogóle ich nie posiadają, a przerwy po lekcjach wf. są zbyt krótkie (lekcje te często odbywają się w środku dnia, między innymi lekcjami).

\section{Podsumowanie i wnioski}

Nabywanie nawyków polegających na świadomym realizowaniu idei zrównoważonego rozwoju związane jest z działalnością edukacyjną szkoły, społeczności lokalnej i instytucji edukacji nieformalnej. Obserwacje własnego organizmu, podejmowanie właściwych decyzji w zakresie zdrowia, działania i akcje prozdrowotne, racjonalna ingerencja w postawy społeczne przekładają się na ochronę zdrowia w wymiarze globalnym.

Omówienie wyników obserwacji uzupełniono dzięki dyskusji ze studentami specjalności nauczycielskiej prowadzącymi badania. Na tej podstawie powstały diagnoza obecnej sytuacji oraz propozycje działań realizujących ideę zrównoważonego rozwoju i podnoszących świadomość uczniów w zakresie dbania o własne zdrowie (tabela 4.). 
Tabela 4. Propozycje zwiększenia świadomości uczniów w zakresie idei zrównoważonego rozwoju w obszarze ochrony zdrowia (zachowano oryginalne zapisy zaproponowane przez studentów)

\section{Jak powinno być?}

1. Powinno się poświęcać więcej uwagi omawianiu następstw różnych chorób.

2. Należy zwiększyć zaangażowanie szkół w działalność społeczną i podnoszenie świadomości uczniów na temat zdrowia.

3. Wiedza na temat diety powinna być realizowana w zakresie niebezpieczeństw i zasad stosowania suplementów diety, środków odchudzających i wspomagających wzrost masy mięśniowej.

4. W sklepikach i stołówkach powinno przeważać zdrowe jedzenie w cenach przystępnych dla uczniów.

5. Boiska szkolne muszą być dostępne nie tylko w czasie zajęć wf.

6. W łazienkach powinny znajdować się prysznice, mydło, papier toaletowy, ręczniki jednorazowe.

7. Zwolnienia $\mathrm{z}$ wf. powinny być weryfikowane przez szkołę.

8. Należy uświadamiać znaczenie badań profilaktycznych dla zachowania zdrowia.

9. Trzeba dogłębnie przedstawiać szkodliwość używek (takich jak narkotyki, papierosy, alkohol).

10. Ważne jest promowanie zachowań zdrowotnych podczas przerw, lekcji, wycieczek szkolnych.

\section{Dlaczego nie jest tak, jak być powinno?}

1. Brakuje konsekwencji w działaniach szkoły (nie nakłada się kar za łamanie zasad, np. palenie papierosów, dostępność niezdrowej żywności, mimo wiedzy o jej szkodliwości).

2. Za mało promuje się zdrowie na lekcjach wychowawczych; uczniowie nie mogą wybrać interesującej ich tematyki.

3. Zaangażowanie władz $\mathrm{w}$ działania na rzecz ochrony zdrowia jest znikome.

4. Brakuje funduszy (stąd niedostateczne wyposażenie szkół, duża liczba uczniów w klasach).

5. Nauczyciele są niedostateczne zainteresowani kształtowaniem świadomości zdrowotnej i wyjaśnianiem wątpliwości uczniów; świadomość skutków złego trybu życia wyniesiona przez uczniów z domów jest niska.

6. Brakuje odpowiednio wykwalifikowanej w zakresie zdrowia kadry nauczycielskiej. 7. Nauczyciele mają za mało czasu, by poświęcić wystarczająco dużo uwagi wszystkim uczniom.

8. Uczniowie nie przykładają wagi do spożywania zdrowych posiłków w odpowiednich warunkach.

9. Zajęcia w szkole zaczynają się wcześnie, więc rano nie ma czasu, by zabrać posiłek $\mathrm{z}$ domu.

10. Zbyt długo wiszące plakaty i ulotki o treściach prozdrowotnych nie pełnią swej funkcji edukacyjnej. 


\section{Dlaczego nie jest tak, jak być powinno? Cd.}

11. Obowiązujący (obszerny) program musi zostać zrealizowany, przez co nauczyciele „nie mają czasu” na jego pogłębianie; wielokrotnie powtarzany i monotonny materiał nudzi uczniów.

12. Uczniowie zmuszani są do robienia zbyt wielu rzeczy (prezentacje, postery, referaty itp.), co przekłada się na niechęć do uczestniczenia w zajęciach.

\section{Co zrobić, aby tak było?}

1. Angażować uczniów w promocję zdrowego stylu życia (np. przez realizację długoterminowych projektów).

2. Dyskutować na temat ochrony zdrowia na godzinach wychowawczych (więcej spotkań z lekarzami, dietetykami, instruktorami fitnessu).

3. Tworzyć projekty i pozyskiwać granty od instytucji promujących zdrowie w celu organizowania akcji o długofalowym charakterze.

4. Realizować zagadnienia związane z zainteresowaniami (i potrzebami) uczniów.

5. Promować edukację zdrowotną przez celebrytów (aktorów, piosenkarzy).

6. Pozyskiwać sponsorów. Zadbać o dobrą relację szkoły z rodzicami.

7. Wycofać automaty ze słodyczami i słodkimi napojami; wprowadzić automaty $\mathrm{z}$ wodą i owocami.

8. W stołówkach i sklepikach oferować zdrową żywność w przystępnych cenach. 9. Urozmaicać lekcje wychowania fizycznego, by wzrosła chęć uczestniczenia w zajęciach.

10. Nie zmuszać uczniów do danego trybu życia, bo wywołuje to odwrotny skutek; należy raczej pokazać wielość alternatyw, np. aktywności fizycznej.

11. Udostępnić sale gimnastyczne, boiska szkolne i sprzęt sportowy poza lekcjami.

12. Ograniczyć możliwości korzystania z nieuzasadnionych zwolnień lekarskich.

13. Dbać o przyjazną atmosferę w szkole.

Źródło: opracowanie własne (na podstawie dyskusji ze studentami biorącymi udział w obserwacji pedagogicznej).

Edukacja dla zrównoważonego rozwoju ma charakter permanentny, szczególnie w zakresie promowania zdrowego stylu życia. Powinna zaczynać się na najniższym etapie edukacyjnym i odbywać poprzez kształcenie formalne i nieformalne. Z całą pewnością to właśnie szkoła jest głównym obszarem realizacji EZR poprzez rozwijanie świadomości i kompetencji uczniów w zakresie podejmowania działań prozdrowotnych na poziomie lokalnym, a następnie krajowym i globalnym.

Zmiany w edukacji zdrowotnej mają na celu opracowanie wzorców edukacyjnych, których wprowadzenie na różnych etapach kształcenia wpłynie na poprawę jakości zdrowia polskiego społeczeństwa. Należy zatem stwarzać warunki, w których wiedza i umiejętności wyniesione ze szkoły będą stosowane w codziennym życiu. Szczególnie ważne jest też podkreślanie potrzeby kształtowania właściwych postaw związanych z zachowaniem zdrowia (jak: prawidłowe odżywianie się, aktywność fizyczna, unikanie używek, poddawanie się badaniom profilaktycznym 
$\mathrm{i}$ inne) oraz ich stopniowe utrwalanie. W ostatnich latach wprowadzono w tym zakresie wiele nowych rozwiązań, jednak aby można było mówić o pełnym sukcesie, należy umożliwić realizatorom EZR (nauczycielom) zdobycie odpowiednich kompetencji zawodowych. Uwagi studentów o konieczności zmian w programach nauczania biologii oraz działaniach szkół nakierowanych na podnoszenie świadomości uczniów w zakresie zdrowia świadczą o potrzebie włączenia na stałe do przebiegu praktyk obowiązku prowadzenia ukierunkowanych, tematycznych obserwacji. Zweryfikowanie tej kompetencji w praktyce daje przyszłym nauczycielom narzędzie świadomej autoewaluacji: weryfikacji celów edukacyjnych i wychowawczych, oceny skuteczności oddziaływań wychowawczych oraz planowania i poszukiwania nowych rozwiązań. Ważna jest również współpraca szkoły z lokalną społecznością i rodzicami, którzy powinni kontynuować i uzupełniać oddziaływania nauczycieli w zakresie edukacji zdrowotnej dzieci.

\section{Bibliografia}

Angrosino M. (2010). Badania etnograficzne i obserwacyjne. Warszawa: Wydawnictwo Naukowe PWN.

Callcott D., Miller J., Wilson-Gahan S. (2012). Health and physical education. Preparing educators for the future. Cambridge University Press, UK.

Davis J.M., Cooke S.M. (2007). Educating for a healthy, sustainable world: an argument for integrating health promoting schools and sustainable schools. „Health Promotion International", 22 (4), 346-353.

Glanz K., Rimer B.K., Viswanath K. (red.). (2015). Health behavior: theory, research, and practice, 5 th edition. San Francisco, USA: Jossey-Bass.

Orme J., Dooris M. (2010). Integrating health and sustainability: the higher education sector as a timely catalyst. „Health Education Research”, 25 (3), 425-437.

Plany i programy studiów na kierunku biologia - Uniwersytet Pedagogiczny Kraków, dostępny na: http://mdl.up.krakow.pl/index.php?option=com_content\&view= category\&layout $=$ blog\&id $=82 \&$ Itemid $=501$ (otwarty 7.03.2016).

Podstawa programowa kształcenia ogólnego z komentarzami. T. 5. Edukacja przyrodnicza w szkole podstawowej, gimnazjum i liceum. Przyroda, geografia, biologia, chemia, fizyka (2009). Warszawa: Ministerstwo Edukacji Narodowej.

Potyrała K. (2011). Kreatywny nauczyciel - wskazówki i rozwiązania. Biologia i przyroda. W: Potyrała K. (red.). Kraków: Wydawnictwo Naukowe UP.

Purchałka M., Czerwiec K. (2013). Assumptions and health education models and their implementation of Polish education system. „Annales Universitatis Paedagogicae Cracoviensis Pertinentia III", Potyrała K. (red.). Kraków: Wydawnictwo Naukowe UP.

Rezolucja Rady Unii Europejskiej (2009), dostępny na: http://erasmusplus.org.pl/ wpcontent/uploads/2014/o8/odnowione_ramy_wsp\% $\mathrm{C}_{3} \% \mathrm{~B}_{3} \% \mathrm{C}_{5} \% 82$ pracy.pdf (otwarty 15.03.2016). 
Rozporzadzenie Ministra Edukacji Narodowej z dnia 27 sierpnia 2012 r. w sprawie podstawy programowej wychowania przedszkolnego oraz kształcenia ogólnego w poszczególnych typach szkół. Dz.U. 2012, poz. 977.

Woynarowska B. (2007). Edukacja zdrowotna. Podręcznik akademicki. Warszawa: Wydawnictwo Naukowe PWN.

\title{
HEALTH-PROMOTING BEHAVIOURS OF YOUTH - PRELIMINARY TEST REPORT CONDUCTED BY THE STUDENTS-FUTURE TEACHERS
}

\begin{abstract}
Sustainable development of society largely depends on the implementation of the concept of education towards respect and protection of human health. Modern education is associated with a tendency to change the approach to school programmes and social knowledge. One of the elements of this knowledge is developing the responsibility for one's own and others health. Due to observation sheets filled out by biology students-teachers to be, the research was carried out in several lower high schools and high schools. The main aim of the research was analysis of the students' health behaviour and realization of the principles of health education in schools. During pedagogical activities students had undertaken some scientific research. It was aimed at improving their competence in the observation of a range of school activities. Analysis of the data relating to the implementation of sustainable development in the area of students health behaviours in the lower high school and high schools has provided information that pro-health awareness is increasing in Polish schools, and the involvement of teachers and students in activities for the benefit of health (hygiene, nourishment, physical activity) is becoming larger and more diverse.
\end{abstract}

Keywords: professional development, sustainable development, education for sustainable development, health education, human health, lower high school, high school, student, teacher

Karolina Czerwiec - doktor, adiunkt w Studium Kształcenia Nauczycieli Wydziału Pedagogicznego Uniwersytetu Pedagogicznego im. Komisji Edukacji Narodowej w Krakowie. Autorka publikacji: Problemy biologii człowieka - implikacje społeczne i edukacyjne (2015), Man biology issues in view of curriculum changes and social transformations (2013), współautorka The role of media and social transformation in forming sex education attitudes (2014). Adres do korespondencji: ul. Podchorążych 2, 30-084 Kraków. Adres e-mail: karolinaczerwiec@gmail.com.

Beata Jancarz-Lanczkowska - doktor, adiunkt w Studium Kształcenia Nauczycieli Wydziału Pedagogicznego Uniwersytetu Pedagogicznego im. Komisji Edukacji Narodowej w Krakowie. Autorka publikacji: Edukacja przyrodnicza z zastosowaniem e-learningu przygotowaniem do uczenia się przez całe życie (2016), Zbiór zadań maturalnych - Zadania. Liceum poziom podstawowy i rozszerzony. Biologia (2010); współautorka Jak odkrywać i rozwijać uzdolnienia przyrodnicze uczniów w szkole podstawowej, gimnazjum i szkole 
ponadgimnazjalnej (2013). Adres do korespondencji: ul. Podchorążych 2, 30-o84 Kraków. Adres e-mail: bjancarz@gmail.com.

Katarzyna Potyrała - dr hab., prof. nadzw. UP w Instytucie Nauk o Wychowaniu Wydziału Pedagogicznego Uniwersytetu Pedagogicznego im. Komisji Edukacji Narodowej $\mathrm{w}$ Krakowie. Autorka The influence of information technology on students' metacognitive competence (2007); współautorka publikacji Teatr naukowy, czyli publiczny dyskurs $z$ nauka i popularyzacja wiedzy (2015) i Fotografia i dydaktyka (2016); redaktorka pozycji Kreatywny nauczyciel - wskazówki i rozwiązania. Biologia i przyroda (2011) i Wybrane problemy popularyzacji wiedzy biologicznej i środowiskowej (2012); współredaktorka publikacji Edukacja przyrodnicza wobec wyzwań współczesności. Podręcznik akademicki (2011), Science Society Didactics (2013) i Natura - człowiek - technologia (2014). Adres do korespondencji: Uniwersytet Pedagogiczny w Krakowie, Wydział Pedagogiczny, Instytut Nauk o Wychowaniu, Katedra Dydaktyk Szczegółowych, 30-06o Kraków, ul. Ingardena 4. Adres e-mail: potyrala2@wp.pl. 